\title{
EFEK PROTEKTIF EKSTRAK ETANOL HERBA PEGAGAN (Centella asiatica (L.) Urban) TERHADAP PEMBENTUKAN KATARAK TIKUS WISTAR YANG DIINDUKSI SODIUM SELENIT
}

\author{
THE PROTECTIF EFFECT OF ETHANOLIC \\ EXTRACT OF GOTU COLA HERB (Centela Asiatica) \\ TOWARD CATARACT FORMATION ON WISTAR \\ RAT INDUCED BY SODIUM SELENITE
}

\author{
Sapto Yuliani \\ Fakultas Farmasi Universitas Ahmad Dahlan Yogyakarta \\ e-mail : syuliani@yahoo.com
}

\begin{abstract}
Abstrak
Katarak adalah penyakit multifaktorial, stres oksidatif diduga sebagai faktor utama pemicu terjadinya katarak. Adanya senyawa yang mempunyai aktfitas antioksidan diharapkan dapat mencegah terjadinya katarak. Pegagan (Centela asiatica) mengandung senyawa asiatikosid yang memiliki sifat antioksidan. Tujuan penelitian ini adalah untuk mengetahui efek protektif ekstrak etanol herba pegagan (Centella asiatica (L.) Urban) terhadap pembentukan katarak tikus Wistar yang diinduksi sodium selenit. Penelitian ini menggunakan tikus Wistar umur 9 hari. Tikus dikelompokkan menjadi 6 kelompok, masing-masing kelompok 5 ekor. Kelompok pertama (kontrol sehat) disuntik aquabides. Kelompok ke-dua (kontrol sakit) disuntik larutan CMC-Na 1\%. Kelompok ke-tiga disuntik Vitamin E dosis $378 \mathrm{IU} / \mathrm{kg}$ BB, kelompok ke-empat disuntik ekstrak etanol herba pegagan dosis pegagan $100 \mathrm{mg} / \mathrm{kgBB}$ secara. Kelompok ke-lima disuntik ekstrak etanol herba pegagan dosis $200 \mathrm{mg} / \mathrm{kgBB}$. Kelompok ke-enam disuntik ekstrak etanol herba pegagan dosis $400 \mathrm{mg} / \mathrm{kgBB}$. Pemberian perlakuan setiap hari selama 3 hari secara intraperitoneal. Empat jam kemudian, semua tikus diberi suntikan sodium selenit dosis tunggal $25 \mathrm{ug} / \mathrm{kgBB}$ secara intraperitoneal. Setelah 7 hari (pada waktu tikus pertama kali membuka matanya) mata diamati secara makroskopis pada semua kelompok. Kemudian tikus dikorbankan, dan mata diambil untuk pembuatan preparat histopatologi lensanya. Berdasarkan hasil penelitian dapat disimpulkan bahwa herba pegagan (Centela asiatica) memiliki efek protektif untuk mencegah terjadinya katarak pada tikus yang diinduksi sodium selenit. Di antara dosis yang digunakan pada penelitian ini yaitu dosis $100 \mathrm{mg} / \mathrm{kg} \mathrm{BB}$,
\end{abstract}


$200 \mathrm{mg} / \mathrm{kgBB}$ dan $400 \mathrm{mg} / \mathrm{kg} \mathrm{BB}$, dosis yang menunjukkan kejadian katarak paling kecil adalah dosis $200 \mathrm{mg} / \mathrm{kg} \mathrm{BB}$

Kata kunci : , Centela asiatica, sodium selenite, histopatologi, lensa

\begin{abstract}
Cataract is one of the eye pathology that can cause blindness. Oxidative stress has been identified as an initiating factor of cataract. The objective research was to study the protective effect of ethanol extract Centela asiatica toward cataract formation on Wistar rat induced by sodium selenite. Cataract was induced in 9 days old Wistar rat, which 5 groups of 7 each. Group I got injection aquadest and the test groups got injection CMC-na (group II), vitamin E dose 378 IU/kg bw (group III), ethanol extract Gotu cola herb dose $100 \mathrm{mg} / \mathrm{kg} \mathrm{bw}$ (group IV), and $200 \mathrm{mg} / \mathrm{kg} \mathrm{bw} \mathrm{(group} \mathrm{V),} 400$ $\mathrm{mg} / \mathrm{kgbw}$, subcutaneously, respectively, for 3 days. After 4 hours, all rats got injection a single dose $50 \mathrm{ug} / \mathrm{kg}$ of $B W$ sodium selenite intraperitoneally. Then eyes were observed in all groups on postnatal day 16, when the eyes of the rat first opened. Then percentage of cataract incidence were calculated. Finally rats were executed, and eyes were taken for lens histophatological analyses with hematoxiline eosin staining. Based on macroscopic and microscopic analyses it can be concluded that ethano extract of Centella asiatica had protective effect toward cataract formation on Wistar rat induced by sodium selenite. The least cataract incidence was showed at dose $200 \mathrm{mg} / \mathrm{kg} \mathrm{bw}$.
\end{abstract}

Keywoord : , Centela asiatica, sodium selenite, histopathologic, lens 


\section{PENDAHULUAN}

Katarak adalah penyebab utama kebutaan di dunia dan hingga saat ini belum ada strategi untuk menekan angka kejadian penyakit ini secara signifikan (Mccarty and Taylor, 2002). Beberapa faktor resiko diidentifikasi sebagai penyebab katarak pada manusia seperti penuaan, diabetes, diare, kekurangan gizi, kemiskinan, sinar matahari, hipertensi, merokok, dan gagal ginjal (Rajesh et al., 2009). Angka kejadian katarak meningkat seiring dengan bertambahnya usia seseorang, katarak yang terjadi pada usia lanjut disebut katarak senilitas. Meskipun katarak adalah penyakit multifaktorial, stres oksidatif diidentifikasi sebagai faktor utama pemicu tejadinya katarak (Zetterstrom et al,. 2005).

Hasil penelitian ilmiah menunjukkan bahwa tanaman, buahbuahan, sayuran, dan biji-bijian adalah sumber antioksidan yang baik dan dapat menekan reaksi berantai radikal bebas dalam tubuh (Basile et al,. 2005). Salah satu tanaman herbal yang mempunyai efek sebagai antioksidan yang kuat adalah pegagan (Centella asiatica (L.) Urban). Pegagan mengandung asiatikosida yang memiliki potensi sebagai antioksidan eksogen yang dapat dijadikan sebagai suplai antioksidan sehingga dapat mencegah stress oksidatif. Dapat dirumuskan suatu permasalahan apakah pemberian pegagan dapat mencegah pembentukan katarak pada model hewan tikus yang diinduksi sodium selenit. Penelitian ini bertujuan untuk mengetahui dan membuktikan manfaat ekstrak etanol daun pegagan untuk mencegah terjadinya katarak terhadap hewan uji berupa tikus putih Wistar berumur 9 hari dan diharapkan penelitian ini dapat meningkatkan pemanfaatan tanaman tersebut di masyarakat, terutama pemanfaatannya sebagai pencegah katarak senilitas.

\section{METODE PENELITIAN}

\section{Bahan}

Herba pegagan, sodium selenit $\left(\mathrm{Na}_{2} \mathrm{SeO}_{3}\right)$, aquabides (produksi Otsuka, Jepang), CMC Na 1\% (pensuspensi ekstrak), etanol $70 \%$, formalin, alkohol $70 \%$, dan $\mathrm{NaCl}$ Fisiologis.

\section{Alat :}

Alat yang digunakan adalah timbangan, mikropipet, jarum suntik volume $1 \mathrm{ml}$, seperangkat alat bedah, dan seperangkat alat-alat gelas, mikroskup, kamera.

\section{Jalannya penelitian}

\section{Penentuan dosis Sodium Selenit}

Berdasarkan penelitian pendahuluan sodium selenit dosis 25 $\mu \mathrm{mol} / \mathrm{KgBB}$ dapat menimbulkan kejadian katarak $100 \%$.

$$
\begin{aligned}
& \mathrm{n}=\frac{\text { Bobot }(\mathrm{g})}{\text { BM Sodium Selenite }} \\
& 25=\frac{\text { Bobot }}{172,938} \\
& \text { bobot }=4,32345 \times 10^{-3} \text { gram }
\end{aligned}
$$

Sodium Selenit diberikan yaitu $4,32345 \times 10^{-3 g r a m} / K g B B$. Konsentrasi larutan yang dibuat adalah $0,5^{\mathrm{mg}} / \mathrm{KgBB}$ dengan melarutkan $25 \mathrm{mg}$ dalam 
aquabides sampai $50 \mathrm{ml}$. Volume maksimal pada tikus 9 hari $0.50 \mathrm{ml}$.

\section{Ekstraksi pegagan}

Pada tahap ekstraksi, sebanyak 250 gram herba pegagan kering ditambah dengan 1,25 liter etanol $70 \%$ diaduk dengan menggunakan stirrer selama 1 jam. Kemudian dimaserasi selama 24 jam. Diulangi 3 kali. Campuran disaring sehingga didapat maserat kemudian diuapkan di atas penangas air hingga didapatkan ekstrak kental.

\section{Penentuan konsentrasi ekstrak}

Dosis ekstrak $100 \mathrm{mg} / \mathrm{kg} \mathrm{BB}=$

$\frac{100 \mathrm{mg} / \mathrm{kgBB} \times 0.015 \mathrm{~kg}}{0,1 \mathrm{ml}}=15 \mathrm{mg} / \mathrm{ml}$

Dosis ekstrak $200 \mathrm{mg} / \mathrm{kg} \mathrm{BB}=$ $\frac{200 \mathrm{mg} / \mathrm{kgBB} \times 0.015 \mathrm{~kg}}{0,1 \mathrm{ml}}=30 \mathrm{mg} / \mathrm{ml}$

Dosis ekstrak $400 \mathrm{mg} / \mathrm{kg} \mathrm{BB}=$ $\frac{400 \mathrm{mg} / \mathrm{kgBB} \times 9.015 \mathrm{~kg}}{0,1 \mathrm{ml}}=60 \mathrm{mg} / \mathrm{ml}$

\section{Perlakuan hewan uji.}

Penelitian ini menggunakan tikus Wistar umur 9 hari yang dikelompokkan menjadi 6 kelompok, masing-masing kelompok 5 ekor. Kelompok pertama (kontrol sehat) disuntik aquabides. Kelompok ke-dua (kontrol sakit) disuntik larutan CMC-Na 1\%. Kelompok ke-tiga disuntik ekstrak etanol herba pegagan dosis pegagan 100 mgram /kgBB secara. Kelompok ke-empat disuntik ekstrak etanol herba pegagan dosis $200 \mathrm{mg}$ / kgBB. Kelompok ke-lima disuntik ekstrak etanol herba pegagan dosis $400 \mathrm{mg} / \mathrm{kgBB}$. Pemberian perlakuan setiap hari selama 3 hari secara intraperitoneal. Empat jam kemudian, semua tikus diberi suntikan sodium selenit dosis tunggal $25 \mathrm{ug} / \mathrm{kgBB}$ secara intraperitoneal (kecuali kelompok kontrol sehat). Setelah 7 hari (pada waktu tikus pertama kali membuka matanya) mata diamati secara makroskopis pada semua kelompok. Kemudian tikus dikorbankan, dan organ mata diambil untuk pembuatan preparat histopatologik lensanya.

\section{Histopatologi lensa}

Preparat histopatologik lensa dibuat dengan pewarnaan rutin hematoksilin dan eosin (H\&E ) sesuai metode standar yang dilakukan di laboratorium Patologi Kedokteran Hewan UGM,

\section{Analisis data}

Data yang diperoleh adalah data kualitatif dari gambaran histopatologik lensa yang dianalisis secara deskriptif dengan membandingkan antara kelompok perlakuan dengan kelompok kontrol.

\section{HASIL DAN PEMBAHASAN}

Hasil penelitian pendahuluan

Penelitian pendahuluan bertujuan untuk mengetahui apakah senyawa sodium selenit $\left(\mathrm{Na}_{2} \mathrm{SeO}_{3}\right)$ mampu menginduksi katarak pada tikus Wistar yang berumur 9 hari. Dosis sodium selenit yang digunakan adalah15 $\mu \mathrm{mol} / \mathrm{kgBB}, 25 \mu \mathrm{mol} / \mathrm{kgBB}$ dan 50 
$\mu \mathrm{mol} / \mathrm{kgBB}$. Metode yang digunakan didasarkan pada penelitian Gupta et al (2003) dengan beberapa modifikasi. Sodium selenit dibuat dalam bentuk larutan dan diberikan secara intraperitoneal. Pelarut yang digunakan adalah aquabides atau water for injection (WFI) karena sodium selenit $\left(\mathrm{Na}_{2} \mathrm{SeO}_{3}\right)$ merupakan suatu garam, sehingga mudah larut dalam air.

Pengamatan dilakukan setelah
Pada percobaaan ini menggunakan hewan uji tikus berumur 9 hari. Pemberian obat yang paling memungkinkan pada tikus yang berumur 9 hari adalah intraperitonial, subkutan, dan intramuscular. Pemberian sodium slenite dan ekstrak pada penelitian ini dilakukan secara intraperitonial. Pemberian secara intraperitonial mempunyai resiko terjadinya infeksi yang cukup besar, apalagi pada penelitian ini hewan uji yang digunakan adalah tikus umur 9 hari. Oleh

Tabel I. Hasil pengamatan makroskopis lensa tikus pada uji pendahuluan untuk mengetahui dosis sodium selenit yang dapat menginduksi terjadinya katarak

\begin{tabular}{|c|c|c|c|c|c|c|}
\hline \multirow{2}{*}{ No } & \multicolumn{2}{|c|}{ Dosis $15 \mu \mathrm{mol} / \mathrm{kg} \mathrm{BB}$} & \multicolumn{2}{|c|}{ Dosis $25 \mu \mathrm{mol} / \mathrm{kg} \mathrm{BB}$} & \multicolumn{2}{|c|}{ Dosis $50 \mu \mathrm{mol} / \mathrm{kg} \mathrm{BB}$} \\
\hline & Kanan & kiri & Kanan & kiri & Kanan & kiri \\
\hline 1. & - & - & katarak & katarak & mati & mati \\
\hline 2. & - & Katarak & katarak & katarak & mati & mati \\
\hline 3. & - & - & katarak & katarak & mati & mati \\
\hline
\end{tabular}

tikus berumur 16 hari karena pada waktu itu tikus mulai membuka matanya. Secara makroskopik pembentukan katarak pada penelitian pendahuluan adalah $100 \%$ untuk dosis $25 \mu \mathrm{mol} / \mathrm{kgBB}$ sehingga berdasarkan hasil tersebut, maka dosis sodium selenit yang digunakan adalah $25 \mu \mathrm{mol} / \mathrm{kgBB}$ yang diberikan secara intraperitoneal.

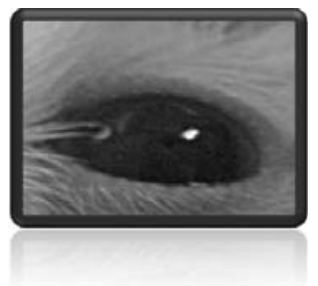

(A) karena itu penyuntikan ke dalam rongga perut harus hati-hati, tidak masuk ke dalam usus atau organ lainnya.

\section{HASIL PENELITIAN}

Hasil penelitian diamati secara makroskopik dan mikroskopik. Pengamatan mikroskopik hasilnya untuk menunjang dan lebih memperjelas peng-

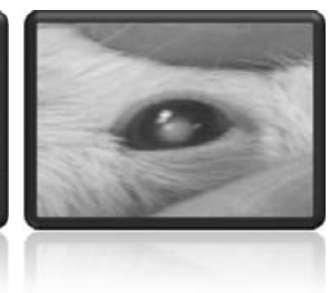

(B)

Gambar 1. Pengamatan secara makroskopik mata yang menunjukkan lensa normal (A) dan yang menunjukkan katarak (B) 
amatan secara makroskopik. Hasil pemeriksaan secara makroskopik ditunjukkan pada Tabel 1 dan Gambar 1.

Pengamatan pembentukan katarak juga dilakukan dengan pembuatan preparat histopatologik lensa untuk mengetahui abnormalitas sel-sel lensa

Lensa mata merupakan salah satu jaringan yang dapat mengalami stres oksidatif dan kerusakan pada lensa mata bersifat irreversible. Modifikasi kimia komponen penyusun lensa yang di-

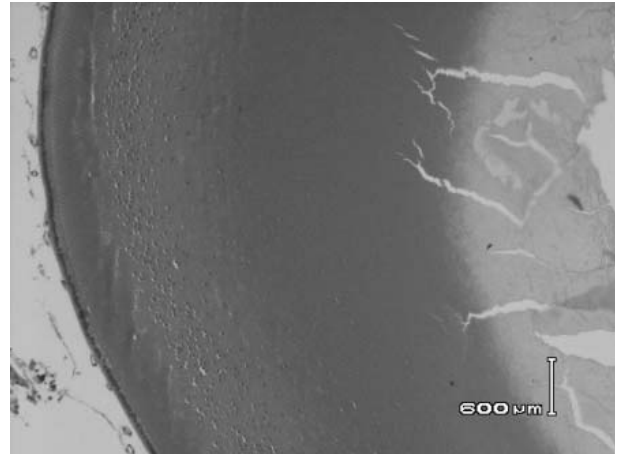

Gambar 2. Gambaran histopatologik lensa normal, pengecatan hematoksilin eosin, perbesaran $200 x$

Tabel II. Hasil pengamatan makroskopik lensa pada semua kelompok perlakuan

\begin{tabular}{|c|c|c|c|c|}
\hline Kelompok & No. Tikus. & Mata kanan & Mata kiri & $\begin{array}{c}\text { \% kejadian } \\
\text { katarak }\end{array}$ \\
\hline $\begin{array}{c}\text { Kel. I } \\
(\mathrm{CMC} \mathrm{Na} \mathrm{1 \% )}\end{array}$ & $\begin{array}{l}1 . \\
2 . \\
3 . \\
4 . \\
5 .\end{array}$ & $\begin{array}{l}\text { normal } \\
\text { normal } \\
\text { normal } \\
\text { normal } \\
\text { normal }\end{array}$ & $\begin{array}{c}\text { normal } \\
\text { normal } \\
\text { normal } \\
\text { normal } \\
\text { normal }\end{array}$ & $0 \%$ \\
\hline $\begin{array}{c}\text { Kel. II } \\
\text { (Sod. selenit } \\
25 \mu \mathrm{mol} / \mathrm{kgBB} \text { ) }\end{array}$ & $\begin{array}{l}1 . \\
2 . \\
3 . \\
4 . \\
5 .\end{array}$ & $\begin{array}{l}\text { katarak } \\
\text { katarak } \\
\text { katarak } \\
\text { katarak } \\
\text { katarak }\end{array}$ & $\begin{array}{l}\text { katarak } \\
\text { katarak } \\
\text { katarak } \\
\text { katarak } \\
\text { katarak }\end{array}$ & $100 \%$ \\
\hline $\begin{array}{c}\text { Vitamin E } \\
378 \mathrm{IU} / \mathrm{kg} \mathrm{BB}\end{array}$ & $\begin{array}{l}1 . \\
2 . \\
3 . \\
4 . \\
5 .\end{array}$ & $\begin{array}{l}\text { normal } \\
\text { normal } \\
\text { normal } \\
\text { normal } \\
\text { normal }\end{array}$ & $\begin{array}{c}\text { normal } \\
\text { normal } \\
\text { normal } \\
\text { normal } \\
\text { normal }\end{array}$ & $0 \%$ \\
\hline $\begin{array}{c}\text { Kel. III } \\
\text { (Ekstrak etanol herb. } \\
\text { peg } \\
\text { dosis } 100 \mathrm{mg} / \mathrm{kgBB} \text { ) }\end{array}$ & $\begin{array}{l}1 . \\
2 . \\
3 . \\
4 . \\
5 .\end{array}$ & $\begin{array}{l}\text { katarak } \\
\text { katarak } \\
\text { normal } \\
\text { katarak } \\
\text { katarak }\end{array}$ & $\begin{array}{l}\text { katarak } \\
\text { katarak } \\
\text { normal } \\
\text { katarak } \\
\text { katarak }\end{array}$ & $80 \%$ \\
\hline $\begin{array}{c}\text { Kel. IV } \\
\text { (Ekstrak etanol } \\
\text { herb.peg } \\
\text { dosis } 200 \mathrm{mg} / \mathrm{kg} \mathrm{BB} \text { ) }\end{array}$ & $\begin{array}{l}1 . \\
2 . \\
3 . \\
4 . \\
5 .\end{array}$ & $\begin{array}{l}\text { normal } \\
\text { normal } \\
\text { katarak } \\
\text { katarak } \\
\text { katarak }\end{array}$ & $\begin{array}{l}\text { normal } \\
\text { normal } \\
\text { katarak } \\
\text { katarak } \\
\text { katarak }\end{array}$ & $60 \%$ \\
\hline $\begin{array}{c}\text { Kel. V } \\
\text { Ekstrak etanol } \\
\text { herb.peg } \\
\text { dosis } 400 \mathrm{mg} / \mathrm{kg} \mathrm{BB}\end{array}$ & $\begin{array}{l}1 . \\
2 . \\
3 . \\
4 . \\
5 .\end{array}$ & $\begin{array}{l}\text { katarak } \\
\text { katarak } \\
\text { katarak } \\
\text { katarak } \\
\text { katarak }\end{array}$ & $\begin{array}{l}\text { katarak } \\
\text { katarak } \\
\text { katarak } \\
\text { katarak } \\
\text { katarak }\end{array}$ & $100 \%$ \\
\hline
\end{tabular}




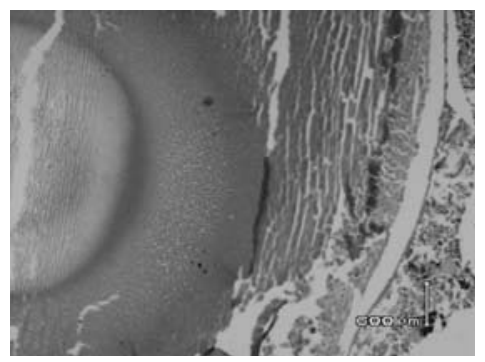

(A)

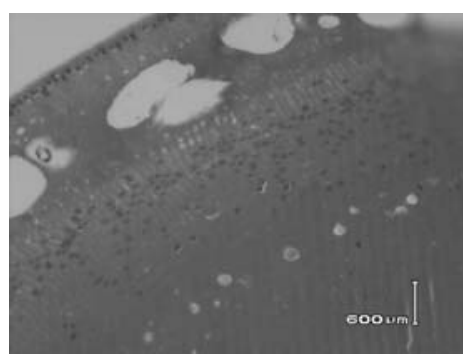

(B)

Gambar 3. Gambaran histopatologik lensa yang mengalami katarak, terjadi deproteinasi lensa (A) dan vakuolisasi lensa (B), pengecatan hematoksilin eosin, perbesaran 200x.

perantarai agen oksidatif dipercaya sebagai penyebab pembentukan katarak karena adanya gangguan homeostatis elektrolit, agregasi protein, dan hilangnya fungsi enzimatik mata (Shanbu et al., 1984).

Berdasarkan hasil penelitian menunjukkan bahwa sodium selenit dapat menginduksi terjadinya katarak. Menurut Gupta et al (2003) pemberian dosis tunggal selenit yang diberikan pada hewan tikus umur muda dapat menyebabkan kataraktogenesis yang mirip secara morfologi dan biokimia pada katarak senilitas yang umumnya terjadi pada orang tua. Model hewan katarak dengan induksi menggunakan sodium selenit dikatakan cukup reproducible dan sering digunakan untuk mengevaluasi potensi antikatarak dengan menggunakan agen-agen yang berbeda. Sodium selenit dapat menyebabkan kerusakan pertahanan oksidatif dan merusak membran sel sehingga memicu pembentukan katarak. Oksidasi membran epitel dan pembentukan agregat protein yang tidak larut merupakan awal terjadinya kekeruhan pada lensa.

$$
\begin{aligned}
& \mathrm{Na}_{2} \mathrm{SeO}_{3}+\mathrm{H}_{2} \mathrm{O} \longrightarrow \mathrm{SeO}_{2}+2 \mathrm{NaOH} \\
& \mathrm{SeO}_{2}+\mathrm{H}_{2} \mathrm{O} \longrightarrow \mathrm{SeO}_{3}{ }^{2-}+2 \mathrm{H}^{+} \\
& \mathrm{SeO}_{3}{ }^{2-} \longrightarrow \mathrm{SeO}_{2}+\mathrm{O}^{2-}
\end{aligned}
$$

Gambar 6. Kemungkinan reaksi terbentukya radikal bebas dari sodium selenit.

(Selim et al., 2001) .

Radikal bebas superoksida dan hidroksil menyebabkan kerusakan terhadap lipid dan protein membran sel yang tersimpan pada permukaan lensa, menyebabkan kekeruhan pada lensa, penurunan kadar plasma askorbat, $\beta$ karoten, dan peningkatan pembentukan kejadian katarak Oleh karena itu diperlukan senyawa antioksidan untuk mencegahnya.

Kelompok tikus yang mendapatkan vitamin E dosis $378 \mathrm{IU} / \mathrm{kg}$ BB menunjukkan semua tikus secara makroskopik tidak mengalami katarak. Dosis pemberian vitamin E dalam penelitian ini didasarkan pada penelitian sebelumnya (Azie, 2008) yang menunjukkan bahwa pemberian vitamin $\mathrm{E}$ dosis $378 \mathrm{IU} / \mathrm{kg}$ BB mampu menghambat pembentukan katarak yang diinduksi sodium selenit. Vitamin E 
merupakan inhibitor radikal bebas sebagai perangkap radikal bebas. Kerja yang lazim suatu inhibitor radikal bebas ialah bereaksi dengan radikal bebas reaktif membentuk radikal bebas tidak reaktif dan relatif stabil. Suatu senyawa dengan gugus $-\mathrm{OH}$ yang terikat pada karbon cincin aromatik seperti vitamin $\mathrm{E}$ atau tokoferol $(\mathrm{Toc} \mathrm{OH})$, merupakan antioksidan yang efektif. Produk radikal bebas senyawa-senyawa ini terstabilkan secara resonansi dan karena itu tidak reaktif dibandingkan dengan kebanyakan radikal bebas lain (Asbel et al., 2005). Adanya aktifitas antioksidan inilah sehingga dapat mencegah oksidasi membran epitel dan pembentukan agregat protein yang tidak larut dan mencegah pembentukan katarak.

Berdasarkan hasil pengamatan makroskopis pada tikus percobaan menunjukkan bahwa pemberian ekstrak etanol herba pegagan pada dosis 200 $\mathrm{mg} / \mathrm{kg}$ BB menunjukkan kejadian katarak yang paling kecil dibandingkan dengan dosis lain. Pegagan mengandung zat aktif yaitu asiatikosida, madecasoside (5,30 dan asiatic acid (Zainol, et al., 2008). Asiatikosida merupakan senyawa yang penting karena memiliki aktifitas antioksidan, yang berperan dalam berbagai aktivitas pencegahan dan penyembuhan penyakit (Satake et al., 2007). Senyawa asiatikosida berperan mengikat oksidan bebas dan menghambat stress oksidatif (Hawse et al,. 2003). Adanya aktifitas antioksidan inilah yang kemungkinan akan mencegah oksidasi lensa sehingga mencegah terjadinya kekeruhan pada lensa (katarak). Dalam penelitian pemberian ekstrak dengan dosis yang lebih tinggi ternyata tidak meningkatkan kemampuannnya untuk mencegah terjadinya katarak. Hal ini dapat disebabkan adanya kandungan senyawa lain dalam ekstrak yang kemungkinan dengan bertambahnya dosis akan mengurangi aktifitas antikatarak dari ekstrak herba pegagan.

\section{KESIMPULAN DAN SARAN}

\section{Kesimpulan}

1. Berdasarkan hasil makroskopik menunjukkan bahwa ekstrak etanol herba pegagan (Centella asiatica) mempunyai efek protektif terhadap pembentukan katarak yang diinduksi oleh sodium selenit pada tikus Wistar.

2. Diantara dosis yang digunakan pada penelitian ini yaitu dosis $100 \mathrm{mg} / \mathrm{kg}$ $\mathrm{BB}, 200 \mathrm{mg} / \mathrm{kgBB}$ dan $400 \mathrm{mg} / \mathrm{kg}$ $\mathrm{BB}$, dosis yang menunjukkan kejadian katarak paling kecil adalah dosis $200 \mathrm{mg} / \mathrm{kg} \mathrm{BB}$

\section{Saran}

Untuk penelitian selanjutnya menggunakan dosis ekstrak etanol herba pegagan dengan dosis diantara dosis 100 $\mathrm{mg} / \mathrm{kg}$ bb dan $200 \mathrm{mg} / \mathrm{kg} \mathrm{BB}$.

\section{DAFTAR PUSTAKA}

Aji B.A., 2008, Efek Protektif Vitamin E Terhadap Pembentukan Katarak yang Diinduksi oleh Sodium Selenite pada Tikus Wistar , Skripsi, Fak. Farmasi, UAD

Asbell, P. A. I. Dualan, J. Mindel, D. Brocks, M. Ahmad, S.Epstein. 2005. Age-related cataracts. Lancet. 365,599-609. 
Basille, A., Ferrara, L., Del Pozzo, M., Mele, G., Sorbo, S., bassi, P., Montessano,D., 2005. Antibacterial and antioxidant activities of etanol extract from Paullina cuppana Mart. $J$. Ethnopharmacol. 102, 32-36.

Hawse, John R., James F. Hejtmancik, Quingling Huang, Nancy L. Sgeets, Douglas A. Hosack, Ricard A. Lempicki, Joseph Horwizt, and Marc Kantorow. 2003. Identification and functional clustering of global gene expression differences between human age-related cataract and clear lenses. New Jarsey. 515:537-9.

Gupta, S.K., Trivedi, D., Srivastava, S., Joshi, S., Halder, N., and Verma, S.D., 2003. Lycopene attenuates oxidative stress induced experimental cataract development an in vitro and in vivo study. Basic Naturally Investigation. University of Maryland. Collage Park. Marylond. USA.

McCarty CA, Taylor HR. 2002, A review of the epidemiologic evidence linking ultraviolet radiation and cataracts. Dev Ophthalmol.;35:21-31.

Pittella, Frederico Rafael C. Dutra, Dalton D. Junior, Miriam T. P. Lopes and Nadia R. Barbosa. 2009. Antioxidant and cytotoxict activities of Centella aciatica (L.) Urban. Departamento de Alimentos Toxicologia e, Faculdade de Farmácia e Bioquímica, Universidade Federal de Juiz de Fora, Martelos, Brasil. 10, 3713-3721.

Rajesh Sinha, Chandrashekhar Kumar, Jeewan S Titiyal, 2009, Etiopathogenesis of cataract: Journal review, R. P. Centre for Ophthalmic Sciences, All India Institute of Medical Sciences, Ansari Nagar, New Delhi, India, Vol. 57 :3, 245-249.

Satake T, Kamiya K, An Y, Oishi T and Yamamoto J. 2007. The anti-thrombotic active constituents from Centella asiatica. Biol. Pharm. Bull. 30(5) 935-940.

Selim Doganay,Yusuf Turkoz,Cem Evereklioglu, Hamdi Er, Mehmet Bozaran, Elif Ozerol, 2001, Use of caffeic acid phenethyl ester to prevent sodium-selenite-induced cataract in rat eyes. Journal of Cataract \& Refractive Surgery, Vol., 28, Issue 8 , Pages 1457-1462.

Shambhu D. Varma, Diwan Chand, Yog R. Sharma, John F. Kuck and Richard D. Richards,, 1984, Oxidative stress on lens and cataract formation: role of light and oxygen, Current Eye Research, 1984, Vol. 3, No. 1 , Pages 35-58

Zainol, N.A.S.C. Voo, M.R. Sarmidi, R.A. Aziz. 2008. Profiling of Centella asiatica (L.) Urban extract. Faculty of Chemical and Natural Resources Engineering, Chemical Engineering Pilot Plant, Universiti Teknologi Malaysia, 
Skudai, Johor Darul Takzim, Malaysia. 12, 322-327.

Zetterstrom, C.A. Lundvall, M. Kugelberg. 2005. Cataracts in children, J. Cataract Refract. Surg. $31,824-840$. 